\title{
Educational Psychology Manifestations In Selected Teen Novels
}

Nik Rafidah Nik Muhammad Affendi, Awang Azman Awang Pawi, Nur Widad Roslan, Roslina Mamat, Rosnani Md Zain

To Link this Article: http://dx.doi.org/10.6007/IJARBSS/v12-i1/11361 DOI:10.6007/IJARBSS/v12-i1/11361

Received: 11 November 2021, Revised: 15 December 2021, Accepted: 30 December 2021

Published Online: 12 January 2022

In-Text Citation: (Affendi et al., 2022)

To Cite this Article: Affendi, N. R. N. M., Pawi, A. A. A., Roslan, N. W., Mamat, R., \& Zain, R. M. (2022). Educational Psychology Manifestations In Selected Teen Novels. International Journal of Academic Research in Business and Social Sciences, 12(1), 265-276.

Copyright: () 2022 The Author(s)

Published by Human Resource Management Academic Research Society (www.hrmars.com) This article is published under the Creative Commons Attribution (CC BY 4.0) license. Anyone may reproduce, distribute, translate and create derivative works of this article (for both commercial and non0-commercial purposes), subject to full attribution to the original publication and authors. The full terms of this license may be seen at: http://creativecommons.org/licences/by/4.0/legalcode

Vol. 12, No. 1, 2022, Pg. $265-276$

Full Terms \& Conditions of access and use can be found at http://hrmars.com/index.php/pages/detail/publication-ethics 


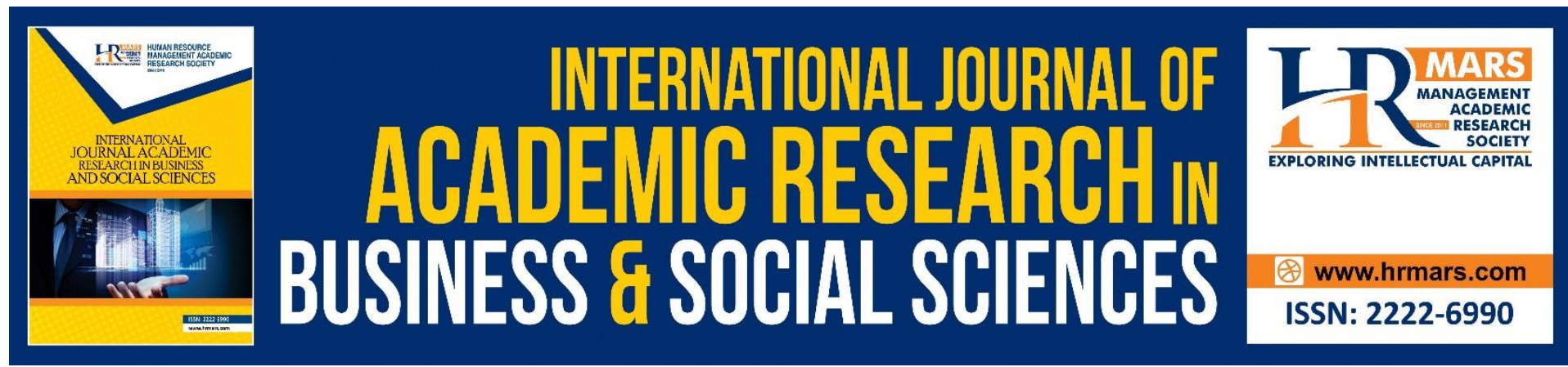

\title{
Educational Psychology Manifestations In Selected Teen Novels
}

\author{
Nik Rafidah Nik Muhammad Affendi ${ }^{1}$, Awang Azman Awang \\ Pawi $^{2}$, Nur Widad Roslan 3 , Roslina Mamat ${ }^{4}$, Rosnani Md Zain ${ }^{5}$ \\ ${ }^{1}$ Department of Malay Language, Faculty of Modern Languages and Communcation, \\ Universiti Putra Malaysia, Malaysia, ${ }^{2}$ Department of Socio-Culture, Academy of Malay \\ Studies, Universiti Malaya, Malaysia, ${ }^{3}$ Language and Communication Division, Faculty of \\ Business, Information and Human Science, Infrastructure University Kuala Lumpur, Unipark \\ Suria, Jalan Ikram - Uniten, 43000 Kajang, Selangor, ${ }^{4}$ Department of Malay Foreign \\ Language, Faculty of Modern Languages and Communcation, Universiti Putra Malaysia, \\ Malaysia, ${ }^{5}$ Department of Malay Language, Faculty of Modern Languages and \\ Communcation, Universiti Putra Malaysia, Malaysia
}

\begin{abstract}
The transition from childhood to adolescence provides a variety of experiences, stress and emotional turmoil to adolescents, especially in school. This indirectly requires the adolescents to manage their psychological elements wisely. One of the psychological elements that should be applied by the author in teen novels is educational psychology. In general, educational psychology is a branch of knowledge that discusses human behavior during the teaching and learning process. Starting from the opinion of literary scholars who stated the appropriateness of educational psychology elements applied by authors of adolescent novels in order to form, encourage and increase motivation in the learning of adolescents to pursue and achieve goals in their lives. In this regard, this study classifies and analyzes the psychological elements of adolescence found in the novel Bening Mata Seorang Dia (2019) by Adnie Bahiah. The Social Learning Theory founded by Albert Bandura was used as a basis in this study. Discussion found three dominant factors that influence the educational psychology of adolescent, which are family, teacher and environmental factors.
\end{abstract}

Keywords: Educational Psychology, Adolescence, Learning, Family, Teachers, Environment

\section{Introduction}

A novel is generally a long story that depicts the turmoil and human life in its society. Meanwhile, a teen novel according to Othman (1989: 31) is a creative work written by the author regardless of age, educational background, geography, politics, race and belief, as long as they are talented and interested. Furthermore, he stressed that teen novels should have a clear message and give a vision and be able to hone and nurture intelligence, translate and appreciate the values of humanity and society and set a good example to the target audience. According to Jumali (2012: 61), teen novels are the result of imaginative creative work that talks about humanity and society, beliefs, culture, politics and economics in human life that 
includes a social picture that is in line with the values and aspirations of teenagers. He stressed that the writing of teen novels should show the sense of belonging and commitment of adolescents which provide information, knowledge, enrich the experience as well as interspersed with positive and nobel values. Its creation cannot be done easily or arbitrarily but requires an author or artist who has expertise.

Based on this view, it can be explained that teen novels are creative works produced for teenage reading, characters and characterisation must display the character of teenagers, narrating life in adolescence which includes various aspects such as politics, economics, social, religion, beliefs and education, which are the closest elements to the teenager's life. Among the issues that are often highlighted in teen novels are the educational psychology element. In short, educational psychology can be defined as the science that studies about human beings in order to know and understand general patterns or principles that emphasize differences between individuals in terms of behavior, abilities, interests, tendencies and so on in the educational process (Zainudin, 2014: 19). Meanwhile, according to Shahabudin, Mahani and Ramlah (2003: 3), educational psychology is the study of human behavior in the teaching and learning process in the classroom to facilitate the teaching and learning process. Haomin \& Jiexin (2021) also claims that educational psychology helps in the process of learning among learners in the classroom.

According to Sri (1989: 2), educational psychology refers to the branch of knowledge that studies the learning process, growth and maturity of individuals as well as the application of principles to human reactions that will affect the teaching and learning process. Educational psychology is a discipline of psychology that investigates problems related to the field of education that emphasizes the principles in the teaching process involved with the findings and applies the principles and ways to improve quality in the field of education (Stefanus, 2018: 2). Based on the scholars' opinion, it can be explained that educational psychology in the context of teen novel research refers to the factors that influence adolescent behavior during the teaching and learning process. The selected teen novel in the study is the novel Bening Mata Seorang Dia (2019) by Adnie The purpose of this study is to classify and analyze the factors that influence the educational psychology elements of adolescent during the teaching and learning process. The novel is also chosen because the teenage characters highlight attitudes and behaviors that lead to the factors influencing the educational psychology elements.

\section{Literature Review}

Basically, psychology and education are different disciplines of knowledge. Psychology talks about human behavior, while education is the process of human teaching and learning. Therefore, these two elements are very close to the human self, especially among adolescents. These two disciplines are combined in literary works. This is because, literature is a social document recorder that records various aspects of human life such as politics, economy, religion, education, psychology and so on (S. Othman, 1987: 16). According to Nurhamizah et al (2017: 73), teen novels highlight many positive things, good things and things that provide teachings and examples, can indirectly be a medium to encourage and increase motivation in a teenager's learning in order to pursue and achieve goals in their lives. This is also supported by Ani (2015: 18-19) who stressed that the educational psychology elements in teen novels should be emphasized by the author. This is because, through literary works, the author provides guidance and teaching that can make teenagers as individuals who are mature, independent, and able to manage life and leadership in the future. Based on the 
two opinions of the literary scholars, it is clear that the psychological management and motivation in learning play a very important role in shaping a certain behavior, image and personality of a teenager. Accordingly, this study will discuss the psychological elements of education found in the selected teen novel.

The researchers who studied adolescent psychology are Nurhamizah, Nursham \& Mohamad (2014). The study discusses the psychological elements of adolescence found in the novel Merdekakan Cinta Ratna by Sri Rahayu Mohd Yusop. The study is based on the Theory of the Hierarchy of Human Needs by Abraham Maslow. Aspects of the study that are discussed are related to the needs of adolescents, namely physiological needs, safety, love and desire to belong, self-esteem and self-fulfillment. However, the psychological aspect of education is not emphasized. In addition, there is also a study conducted by Norlidza \& Hashim (2015), entitled Components of Personal Awareness in Selected Teen Novel. Three teen novels, namely the Trilogi Cinta, Impuls/Roh and Warsinya Kalbu are used as the study material. This study discusses the psychological element of adolescence from the emotional aspect. The findings of the study found that the three teen novels meet the three components of personal awareness, namely recognizing one's own emotions, managing emotions and selfawareness as outlined in the Theory of Emotional Intelligence by Mayer, Curaso and Salovey and the Theory of Emotional Intelligence by Daniel Goleman. This study only focuses on the psychological aspects of adolescence, which is the element of personal emotions that are not associated with educational psychology.

Next, a study conducted by Khariah \& Denna (2016) entitled Character and Characterization Analysis in the novel Sejambak Bakti written by Rejab FI. This study analyzes the character and characterisation of adolescents using Sigmund Freud's Theory of Psychoanalysis. The analysis found that the three components of id, ego and superego are described through the actions of adolescent characters in dealing with problems encountered such as family problems and friendship. However, this study does not detail the psychological elements of education, although the theme of the novel is on the story of adolescent's life in the school environment. The study on the Elements of Conflict in Teen Novel is also conducted by Faziela \& Nik Rafidah (2016). The results showed that the novel 6:20 by Siti Jasmina (2001), Merenang Gelora by Ruslan (2002); Azfa Hanani by Halis (1995) touched on family, internal and peer conflict. Based on the research, the researcher also found that the conflict that occurs can be handled by adolescents involved in the conflict. All characters succeed in life after facing various conflicts. Accordingly, this study looks at aspects of conflict from the perspective of Maslow's theory.

Furthermore, a study is conducted by Nurhamizah et al (2017) on Maslow Psychological Elements in Selected Novel. This study focuses on the aspects of security needs required by adolescent characters, which are physical security, emotions and economic stability by applying the Theory of Hierarchy of Human Needs (Abraham Maslow). Researchers only focus on the psychological aspects of safety that are not associated with the educational psychology elements.

Based on the literature review of the previous studies on the psychological elements in teen novels, researchers found that these studies only focus on a few psychological elements such as physiological needs, safety, love and desire to belong, self-esteem, self-improvement and emotional elements of adolescents. Therefore, this study needs to be done to fill the study gap by discussing the educational psychology elements of adolescents in selected novels. 


\section{Methodology}

This study is using the Social Learning Theory founded by Albert Bandura in 1977 as a basis for research. Ma'rof \& Haslinda (2008: 161-162) stated that among the three main ideas of Bandura related to human behavior are reciprocity, self-efficacy and self-organization. Bandura stated that personal or cognitive factors (beliefs, expectations and perceptions), one's behaviors all influence each other and are influenced by one another. This reciprocal relationship is termed by Bandura as a reciprocal determinism. Therefore, these factors influence (determine) and are influenced (determined) by each other.

One of the important cognitive factors according to Bandura is self-efficacy. Self-efficacy refers to the human perception of the ability to do something efficiently and successfully in whatever action is taken (Kaiye et al., 2020). Strictly speaking, it depends on the extent to which a person believes that he or she can efficiently behave as needed in order to produce a goal and achieve their desire. Self-efficacy also determines the choice of activity or occupation, seriousness and tenacity of a person in the face of various obstacles to achieve that goal. A person who has self-control will act in a new situation by setting high and continuous goals in the endeavor and believe that success will be achieved. On the other hand, a person with low self-esteem often expects to experience failure and avoid challenges, easily give up when faced with difficulties and easily experience stress and depression. Selfregulation refers to the learning process by observing the behavior of others. According to Bandura, children and teenagers learn a lot through imitation. Adolescent behavior results from the experience when they grew up. Therefore, most adolescent behaviors are in accordance with the wishes of parents and society. Deviant behavior is the result of imperfect parenting and socialization processes. Changes in society in turn result in changes in perceptions of society (Zakaria et al., 2012: 156).

In this regard, the Social Learning Theory founded by Albert Bandura is very relevant in analyzing the psychological elements of adolescent education. This is because, these three principles emphasize aspects of behavior and psychiatric symptoms that are related to the learning process. Thus, the psychological approach is able to describe human behavior in the novel studied. A summary of Social Learning Theory can also be seen in the diagram below.

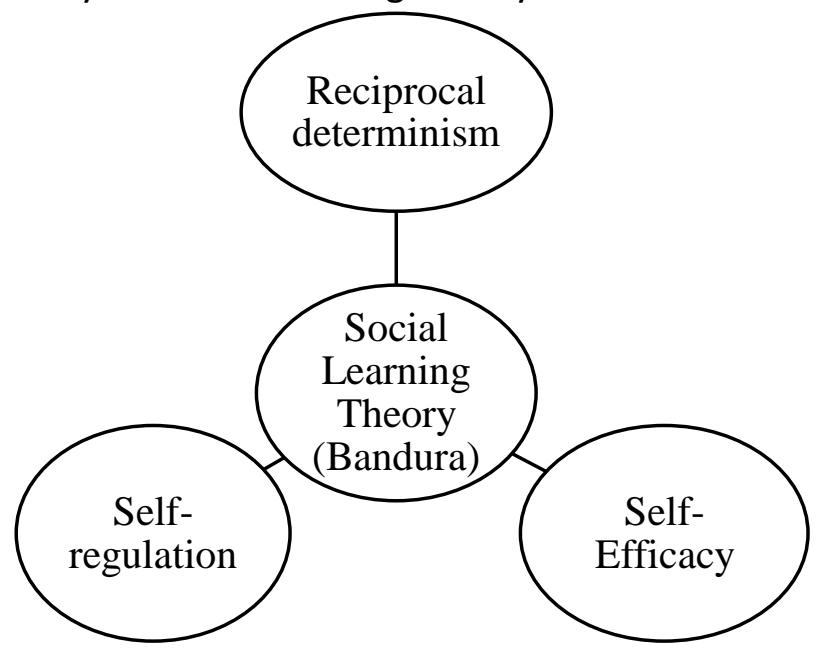

Figure 1: Social Learning Theory

\section{Synopsis}

Adnie's novel, Bening Mata Seorang Dia (2019) was published by Dewan Bahasa dan Pustaka was selected as the subject of study. This 111-page novel tells the story of the emotional turmoil that Azie Raihana went through after the death of her mother due to breast 
cancer. The loss of her beloved mother greatly interrupted Azie's learning because she could not concentrate fully on her studies. However, the presence of Cikgu Fazlee managed to cheer up the heart of the teenager who had long lost her place to be happy. Armed with interest, determination and perseverance, Azie finally succeeded in her studies with excellence and achieved her ambition to become a writer.

\section{Results and Discussion Family Factor}

Family refers to a group of people united in a marriage, blood or by adoption. A basic family consists of a mother, a father and children living together in a house. The function of the family is focused on the role of parents, that is to provide love, alimony, protection and education to the children. However, families with problems or difficulties will have a profound effect on the educational psychology of children. According to a study conducted by Azyyati, Fariza \& Salasiah (2013: 111-119), it is found that the main causes of adolescent learning problems are due to dysfunctional family institutions, families with low socioeconomic status and problems in the current academic education and due to irrational thinking system.

Based on the novel Bening Mata Seorang Dia (2019), the author clearly shows the learning problems experienced by the character Ida Raihana. A week after her mother's death, Ida dropped out of school because she wanted to help her father take care of her two younger siblings. Here, it is clear that her father did not play a role in preventing Ida from leaving school and not taking the Sijil Tinggi Pelajaran Malaysia (STPM) examination which is only two weeks away, in fact her father seems to encourage his daughter to do the same. As a father, he is responsible for providing awareness to his children about the importance of education for a better future.

"Kak Ida is not going to school, had dropped out. Kak Ida wants to take care of my siblings".

(Bening Mata Seorang Dia, 2019:52)

Thus, what stated by Zakaria et al (2012: 155) is true that parents play an important role in shaping the education of children and form the foundations of a child's selfdevelopment. Parents can help their children get an excellent and quality education. Therefore, they are responsible for forming a positive attitude in children such as wanting to learn, diligently reading, curious, like to socialize and mingle with others, always active and participate in school activities.

The death of a beloved mother puts so much pressure on the children that they have to earn their own money to survive. In the novel, the author describes Kak Ida opening a cup cake business to help ease the financial burden that her father had to bear. Income as a construction worker paid according to the number of working days adds to the burden of the family. Thus, Kak Ida as the eldest child in the family had to drop out of school, sacrificed her ambition to become a teacher and find additional income to ease the financial burden of their father. The situation can be traced in the passage below:

"Azie! Don't be sad anymore. Kak Ida now has my own business. Look at Kak Ida making a cup cake, this can be a 
source of livelihood for our family later. Insya-Allah, if we

try, we will definitely succeed, right?"

(Bening Mata Seorang Dia, 2019:53-54)

Dropping out of school also prompted Kak Ida to get married at a young age. At the age of 19, a teenager the same age as Kak Ida is still in school and busy studying for the Sijil Tinggi Pelajaran Malaysia (STPM).

Today, Kak Ida will be asked for marriage by Aunt Ramlah's son, Anas, Cikgu Fazlee's cousin.

(Bening Mata Seorang Dia, 2019:102)

The situation can be attributed to Borhan's attitude as a father who failed to play a role in giving encouragement and motivation to Kak Ida on the importance of education and career. This is in line with the opinion of Norhidayah and Norhayati (2018: 590), whom asserted that a father should not only give motivation about academics and emphasize on their future, more importantly, a father needs to provide solid support so that their children can achieve what their children want.

In addition, the author highlights the character of a 17-year-old teeager named Azie Raihana who could not concentrate during the learning sessions although she was very interested in the subject of Bahasa Melayu. Her mind was disturbed by the death of her mother who had been very supportive and concerned about her academic development. Her father was busy working and did not care about the children's education. The situation can be seen in the passage below:

During the learning period, my mind totally cannot focus on the subject although Bahasa Melayu is my favorite subject. My memory goes back to mom.

(Bening Mata Seorang Dia, 2019:14)

Azie is also involved in the symptoms of skipping classes. Since the death of her mother, Azie has not been in class for two weeks and only reviewed lessons at the library. From a psychological point of view, Azie's attitude is referred to as an escapism, which is the tendency to run away from accepting bitter situations by doing activities that can give them peace of mind such as reading books at the library. This attitude caused Azie to lag behind in her learning for two weeks as stated in the passage:

"You haven't been to class for two weeks, why Raihana?" he asked while taking the book on the shelf and turning it over.

(Bening Mata Seorang Dia, 2019:44)

This situation experienced by Azie is closely related to the communication problems in the family. After the death of her mother, Azie had no place to express her feelings. His father was busy working and did not focus on the development of the children. Regarding this, Aziyah (2015: 11-28) has stated that the parent's communication pattern in the form of 
conversation by giving a lot of supportive words to children will create children who are happy with themselves, their families and their environment.

Furthermore, the author highlights the character of a 15-year-old teenager, Ayu Raihana, who is the third child of Borhan and his late wife, Rosiah. Ayu is described as a stubborn teenager and likes to rebel when her wishes are not fulfilled by her father. Ayu wants to own a motorcycle used by Kak Ida, but her father has sold the motorcycle. This caused Ayu to get angry and sulk with her father so much that she was willing to ride a motorcycle with a man her age as a sign of protest. Ayu's actions caused Borhan to scold and hit his daughter. Things got worse when Tuk Ayah and Mak Ana took Borhan's children to stay with them at Tuk Ayah's house. This can be seen in the following passage:

\section{"Ayu! Since when did you dare ride with a guy?"}

(Bening Mata Seorang Dia, 2019:99)

Based on the above quotation, the author indirectly described the stress and psychological symptoms experienced by Borhan's children after the death of their mother. Among the psychological symptoms emphasized by the author through the character of Ida who had to quit school because she wanted to help her father financially, take care of her younger siblings and get married at a young age. Azie's character, on the other hand, has trouble concentrating during the teaching and learning process and starts skipping classes. While Ayu's action of riding a motorcycle with a man is one of the psychological symptoms experienced by teenagers because her wishes are not fulfilled. Thus, it can be said that the collapse or damaged family has a great impact on the psychological education of adolescent.

In this regard, Bandura states in the Social Learning Theory, these factors are associated with personal or cognitive (beliefs, expectations and perceptions), a person's behavior all influence each other and are influenced by each other. This reciprocal relationship is termed by Bandura as a reciprocal determininism. Therefore, these factors influence (determine) and are influenced (determined) by each other. This is clearly the case when it can be seen that the psychological symptoms experienced by the eldest sister affect the other siblings. They situation can be considered as adolescents with learning difficulties after the death of a beloved mother.

\section{Teacher Factor}

In addition to family factor, teacher factors also contribute to the educational psychology problems of adolescent. Teachers are important educators after parents. Teachers must carry out the trust given, which are to educate, guide and teach students under their care with full dedication and responsibility. The holistic education received in school affects the academic performance of students. Therefore, teachers need to provide a conducive environment as well as creative teaching techniques in order to attract students during the implementation of the teaching and learning process.

Based on the novel Bening Mata Seorang Dia (2019), the author described the character of Cikgu Maimunah who likes to babble and is not good at attracting students to focus on what is taught has created a noisy atmosphere, and there are students who sleep and chat with each other another. Such a situation can be seen in the passage below: 
After the Bahasa Melayu subject, it's time for Physics. I feel like I just want to get out of this Physics lab. Some more, I am weak in this elective subject. Not that she is not interested because this subject is being taught in English, thinking about the teacher, Cikgu Maimunah, her heart continued to feel cluttered and bored. Cikgu Maimunah, if she is babling, it is very boring. She does not seem to know how to attract her students to what is being taught.

(Bening Mata Seorang Dia, 2019:21)

Based on the example of the passage, according to Ahmad, Kamarul and Khairunnisa (2016: 55), it is the role and responsibility of a teacher to attract students to the subject, stimulate and increase students' curiosity, and motivate them for learning. The above situation is also in line with Bandura's opinion which states that self-regulation refers to the learning process by observing the behavior of others. According to Bandura, children and teenagers learn a lot through imitation. Students need a teacher's touch for them to be better, especially in the teaching and learning process in school. Therefore, teachers need to be the best model for students.

\section{Environmental Factor}

The environment also affects the psychology of adolescent education. In general, environment can be understood as the surrounding area. In the context of this analysis, the environment that affects adolescent psychology is the interaction of adolescents with the society. Such interaction will affect the thinking of adolescents either in a positive or negative direction. A positive environment is very important for adolescents as an impetus and motivation towards excellence in education. In addition, a positive environment also influences adolescents to develop their talents, interests and potential.

Based on the novel Bening Mata Seorang Dia (2019), the author emphasizes the importance of educational psychology through a positive environment to develop the interests, talents and potential of adolescents. The situation is shown through the description of Azie's character who is interested in becoming a writer. Azie faces various obstacles to achieve that ambition. Among them, Azie was stopped by her father and was beaten for attending a writing workshop at the Dewan Bahasa dan Pustaka Wilayah Timur in Kota Bharu. Apart from that, Azie also experienced disappointment when she found that her beloved Cikgu Fazlee had tied the knot with a girl. However, Azie has a high spirit and perseverance until she managed to continue her studies at one of the matriculation centers in the city. Azie's poems have also been published in periodic newspapers and magazines published by Dewan Bahasa dan Pustaka. In this regard, the positive environment of advice and motivation from people around such as Pak Jusoh, Cikgu Fazlee, Kak Ida and Tuk Ayah encouraged Azie's success in education in line with her interest in becoming a writer. The situation can be traced in the passage below:

I managed to continue my studies at one of the matriculation centers. Who would have thought that eventually I would be able to realize the aspirations of my late mother who wants me to be a doctor? After a year of studying at the matriculation level, I would continue my 
studies in Indonesia majoring in medicine. And writing, of course I would keep writing. That is my interest and also my soul, even though I do not make the field of writing as a professional field as my career later.

(Bening Mata Seorang Dia, 2019:108)

Based on the above quotation, the author indirectly portrays a positive adolescent character who does not easily give up on achieving her ambitions and desires to become a writer. Obstacles are used as stepping stones to be more successful. Thus, Azie's character is in line with Bandura's opinion which associates Social Learning Theory with the self-efficacy possessed by adolescents on the ability to do things efficiently and successfully in whatever action they do. A person who has self-perseverance will act in new situations by setting high and continuous goals in the endeavor because he or she believes that success will be achieved, as portrayed through Azie's character who not only succeeds in academics but her writing talent is also discovered and has the potential to be a great writer.

\section{Conclusion}

To sum up, the results of the study show that the three teenage characters, Azie, Ida and Ayu, faced learning difficulties because they are influenced by imperfections in the family, teachers and social environment in accordance with Albert Bandura's Theory of Social Learning which emphasizes three main ideas in identifying adolescent education psychology based the behaviors highlighted by adolescents, which are the aspects of reciprocal deerminism, self-efficacy and self-regulaion. The analysis of the study also shows that family factors play an important role in influencing the psychological education of adolescent. Teenagers need the full support and encouragement of their parents to improve their academic performance. Deficiencies in family institutions cause adolescents to experience emotional stress such as not being able to concentrate on lessons, skipping classes, stopped studying and faced emotional turmoil that cannot be handled properly. In addition, the teacher factor also leads to the psychological education of adolescent. Teachers who are not good at drawing students' attention to subjects that are not of interest will cause students' academic performance to decline. The social environment also influences the psychology of adolescent education. Adolescents need to associate with a group of people who can build their potential. Ongoing motivation, advice and support received from those around them will help teenagers to develop their talents, inclinations and interest. Therefore, the study conducted shows that the psychological element of adolescent education should be emphasized in the literary work of adolescents in order to know the problems faced by these groups during the teaching and learning process. In this case, all parties, namely parents, teachers and the community need to work together to provide a conducive environment and not give too much stress to the adolescents in their age which they tried to recognizing their potential. This study is parallel to the study of Faziela \& Nik Rafidah (2016), Nurhamizah, Eizah \& Yuhanis (2017); Haomin \& Jiexin (2021) where adolescent education plays a major role in social environment. Also, this study helps to motivate adolescent to lessen their stress and focus of their learning. It is hoped that further studies will focus on other literary work that among adolescents. 


\section{Corresponding Author}

Nik Rafidah Nik Muhammad Affendi

Department of Malay Language, Faculty of Modern Languages and Communication, Universiti

Putra Malaysia, Malaysia

Email: nrafidah@upm.edu.my

\section{References}

Adnie, B. (2019). Bening Mata Seorang Dia. Kuala Lumpur: Dewan Bahasa dan Pustaka.

Ahmad, F. M. N., Kamarul, A. J., \& Khairunnisa, A. S. (2016). Masalah Sosial dalam Kalangan Pelajar dan Peranan Pensyarah Pendidikan Islam dalam Pengajaran dan Pembelajaran. e-Bangi: Journal of Social Science and Humanities. Jilid 11 (2), 51-6.

Ani, H. O. (2015). Pendidikan Sastera Remaja di Malaysia dalam Membina Generasi Unggul Berasaskan Falsafah Pendidikan Negara. PENDETA- Jurnal Bahasa dan Sastera Melayu. Jilid 5(2-24).

Aziyah, A. B. (2015). Komunikasi Keluarga dan Pengurusan: Dari Perspektif Remaja Melayu. Jurnal Pengajian Media Malaysia. Jilid 17 (1), 11-28.

Azyyati, M. N., Nazim, F. M. S., \& Salasiah, H. H. (2013) Ciri-ciri remaja berisiko: kajian literatur. Islamiyyat: Jurnal Antarabangsa Pengajian Islam; International Journal of Islamic Studies, 35 (1). pp. 111-119. ISSN 0216-5636.

Haomin, Z., \& Jiexin, L. (2021). Morphological knowledge in second language reading comprehension: Examining mediation through vocabulary knowledge and lexical inference, Educational Psychology, DOI: 10.1080/01443410.2020.1865519.

Jumali, S. (2012). Sejarah Perkembangan Novel Remaja di Malaysia. Kuala Lumpur: Dewan Bahasa dan Pustaka.

Kaiye, D., Yan, W., Xuran, M., Zheng, L., Ling, W., \& Baoguo, S. (2020). Achievement goals and creativity: the mediating role of creative self-efficacy, Educational Psychology, 40:10, 1249- 1269, DOI: 10.1080/01443410.2020.1806210.

Ma'rof, R., \& Haslinda, A. (2008). Psikologi. Mc Graw Hill Education.

Nurhamizah, H., Eizah, M. H., \& Yuhanis, M. N. (2017). Unsur Psikologi Maslow dalam Novel Terpilih. PENDETA Journal of Malay Language, Education and Literature. Jilid 8, (72-81).

Nursham, A. A., \& Mokhtar, M. A. H. (2014). Eksplorasi Keperluan Remaja Dalam Novel Merdekakan Cinta Ratna. Jurnal Pengajian Melayu, Jilid 25 (175- 199).

Norhidayah, H. A., \& Norhayati, M. N. (2018). Penglibatan Bapa Terhadap Kesejahteraan Anak-Anak dalam Kalangan Anggota Polis: Satu Kajian Kes di KEM PGA. 2018. Prosiding Seminar Kebangsaan Majlis Dekan Pendidikan Universiti Awam, 7-8 November, 590598.

Othman, P. (1989). Sastera Remaja Ditinjau Daripada Pelbagai Perspektif. Kuala Lumpur: Dewan Bahasa dan Pustaka.

Shahabudin, H., Mahani, R., \& Ramlah, J. (2003). Psikologi Pendidikan. Kuala Lumpur: PTS Professional Publishing Sdn. Bhd.

Siti Khariah, M. Z., \& Denna, N. S. (2016). Analisis Watak dan Perwatakan Dalam Novel Sejambak Bakti Karya Rejab FI. International Seminar on Generating Knowledge Through Research, UUM-UMSIDA, 25-27 October 2016, Universiti Utara Malaysia, Malaysia. 73-80.

S.Othman, K. (1987). Kecenderungan baru dalam novel Melayu: satu kajian struktur. Kuala Lumpur: Dewan Bahasa dan Pustaka.

Sri, E. W. D. (1989). Psikologi Pendidikan. Edisi 2. Yogjakarta: Grasindo. 
Stefanus M. M. (2018). Psikolgi Pendidikan. Uwais Inspirasi Indonesia.

Norlidza, W. M. Z., \& Hashim, I. (2015). Komponen Kesedaran Peribadi Dalam Novel Remaja Terpilih. Jurnal Pengajian Melayu, Jilid 26 (117-139).

Zainudin, A. B. (2014). Psikologi Pendidikan: Pedoman Untuk Guru dan Ibu Bapa. Singapura: Partridge Sdn Bhd.

Zakaria, S., Ahmad, M. I., \& Norazinah, Y. (2012). Faktor Persekitaran Sosial dan Hubungannya dengan Pembentukan Jati Diri. Jurnal Hadhari Special Edition. 155-172. 